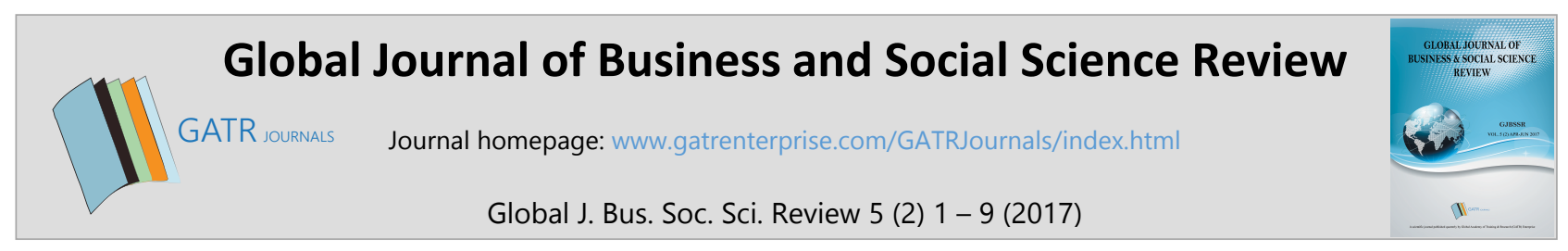

\title{
The Application of Bandura's Social Learning Theory in the Teaching of Academic Writing
}

\author{
Zarihan Samsudin $^{1 *}$, Zainon Shamsudin ${ }^{2}$ and Mohd. Faisal Mohd Arif ${ }^{3}$ \\ ${ }^{1,3}$ School of Humanities and Social Sciences, Kolej Universiti Poly-Tech MARA Kuala Lumpur, Jalan 6/91, Taman Shamelin \\ Perkasa, 56100 Cheras, Kuala Lumpur, Malaysia. \\ ${ }^{2}$ Faculty of Education and Social Sciences, Universiti Selangor (UNISEL), Bestari Jaya Campus, Jalan Timur Tambahan, 45600 \\ Bestari Jaya, Kuala Selangor, Selangor, Malaysia.
}

\section{ABSTRACT}

Objective - This experimental study seeks to ascertain whether Bandura's (1977) Social Learning Theory can be used to teach academic writing. Interpreted in terms of an approach to the teaching of writing, the theory suggests that students can learn to write a particular text by observing closely the structural as well as the linguistic features of that text.

Methodology/Technique - By observing how the text is written, students obtain an idea of how it is formed, and on later occasions they can use this information as a guide to produce similar texts. The sample of this study consists of 100 students from College University Poly-Tech MARA, Kuala Lumpur. The study adopts a pre/post-assessment of the students' writing performances for three types of academic essays. T-tests were used to compare the results of the 3 pretests with the results of the 3 post-tests which were administered to the participants after they underwent each of the 3 treatment sessions.

Findings - The study reveals that the Social Learning Theory speaks the truth about the human natural learning process. Thus, this implies that this potent theory be used in designing varying approaches to teaching students the skills to write academic texts.

Novelty - The study suggests that observational learning of sample texts provides students with guidance on how to improve their writing as it makes them aware of the different ways texts are organized for different communicative purposes, thereby promoting their confidence and positive attitude towards writing.

Type of Paper: Empirical.

Keywords: Academic Writing; Social Learning Theory; Observational Learning; Analyzing; Emulating; Model Text. JEL Classification: I21, I25.

\section{Introduction}

Of the four language skills, students seem to find writing the most difficult to master (Bidabadian \& Tabatabaei, 2015; Sahin \& Genc, 2015; and Samsudin, 2013). Fortunately, there are at present three approaches to the teaching of writing. However, there are many, often conflicting, views as to which is the best approach to be used. The genre-based approach, for example, is an approach to teaching writing through

\footnotetext{
* Paper Info: Revised: October 31, 2016

Accepted: April 14, 2017

* Corresponding author:

E-mail: zarihan@gapps.kptm.edu.my

Affiliation: School of Humanities and Social Sciences, Kolej Universiti Poly-Tech MARA, Malaysia.
} 
the study of linguistic behavior in institutionalized academic or professional settings (Bhatia, 2002). It is an approach to the teaching of writing that bears the closest resemblance to observational learning, which accentuates the significance of observation, modelling and imitation. This approach proposes that students be taught writing by observing and imitating models of genres on how to make language patterns so as to create not only an ideal but purposeful composition (Hyland, 2003a). It assumes that students are usually able to write a particular text relatively easily because they are able to draw on their repeated experiences of frequently dealing with texts similar to the one they are writing (Hyland, 2004, 2007). In view of this, the current study seeks to ascertain whether a genre-based approach that is specifically designed to embody observational learning, developed based on Bandura's social learning theory, is effective in developing students' ability to write academic texts.

\section{Literature Review}

Since its first proposal by Albert Bandura in 1971, the social learning theory has become the most dominant theory of learning that has had significant implication in the field of education (Cherry, 2016). It is based on this theory that the observational learning concept was developed. Bandura (1977) alleges that if it weren't for observational learning, 'learning would be exceedingly laborious, not to mention hazardous, if people rely solely on the effects of their own actions to inform them what to do. Fortunately, most human behavior is learned observationally through modelling; from observing others, one forms an idea of how new behaviors are formed and on later occasions, this information serves as a guide for action' (Bandura, 1977, p. 2). In learning to write, however, the act of analyzing or observing a model text can cause learning to occur 'as a result of partly emulation and partly understanding and conscious application of rules' (Badger and White, 2000, 156).

According to this theory, observational learning occurs as a result of four interrelated sub-processes, namely; attentional processes, retention processes, motoric reproduction processes and reinforcement processes (Bandura, 1977, pp. 6-8). These sub-processes can be interpreted in the following way in terms of learning to write academic texts. Firstly, students need to pay attention to their instructor's observation or analysis of the model text to be learned. Secondly, the ability to store information is vital to observational learning. Once students are able to retain what they have been shown and taught, they are ready for the third sub-processe, which is reproducing the text. While they do so, students are allowed to copy or emulate parts of the model text so as to practice what they have learned, leading them to improve their skills. Finally, while going through the entire process of observational, students need to be given motivation in the form of reinforcement and punishment. For students, personally experiencing reinforcement (expressions of approval and commendation) or punishment (expressions of disapproval and criticism) is highly effective, as much as observing other students experiencing these motivators (Bandura, 1965).

The approach used in this study also looks upon writing as largely linguistic (Atkinson, 2003; Cheng, 2006, 2007, 2008; Hyland, 2003a, 2003b, 2007; Johns, 2003; Paltridge, 1996, 2000, 2002, 2004, 2007; Swami, 2008). Students can be taught to identify the recursive features of any genre employed in academic and professional settings 'through consciousness-raising and linguistic awareness tasks' (Ahn, 2012, p.3). Once students are aware of the salient features of a genre, they can produce examples of these features on their own. Ahn (2012) refers to such observations as an "active scaffolding processes" which she believes are most useful to students as the different ways texts are written are overtly pointed to them. Carrying them out at an early stage of the writing cycle is indeed preferable as they help develop and raise students' confidence levels and positive attitude towards writing (Ahn, 2012, p.2). The assertion of the effectiveness of the scaffolding process is also supported by Badger and White (2000), Chow (2007), Md Omar, Lee, and Jamil (2013), Hyland (2003a, 2004), Johns (1997), Maleerat Ka-kan and Sarjit Kaur (2015), Martin (1993), Ting et al (2013), Sajid and Saddiqui (2015), Siallagan (2014) and Schweitzer (as cited in Zangoei and Davoudi, 2016). The findings of Schweitzer's (as cited in Zangoei and Davoudi, 2016) study for example, indicate that the scaffolding techniques within Vygotsky's (1978) Zone of Proximal Development or ZPD can actually enhance second 
language writing skills. Vygotsky (1978) recommends that an instructor, through cooperative or collaborative dialogue, provide students with appropriate assistance when they are in the ZPD for a certain task so as to will boost their confidence.

Producing a coherent and cohesive text to meet specific academic requirements is generally difficult for many students (Flowerdew as cited in Johns, 2002). However, according to Osman (2004), through a genre analysis, students can learn the generic features of any type of genre that provides them the insight into the working of the genre. This understanding of the structural patterns of the target genre enables students to identify the strategies used by writers to achieve their communicative purposes and the occurrence of obligatory and optional moves and the sequence in which these moves occur. Md Omar et al (2013), Badger and White (2000) and Martin (1993) are among those who uphold the same beliefs as Osman (2004). Genre forms are best taught explicitly through observation of models texts so that they are able to learn the elements of different genre forms and the ways they are sequenced (Martin, 1993). Furthermore, since the genre-based approach in this study is similar to any other genre-based approaches, it too considers writing as largely linguistic thus, enabling students to learn how linguistic means can be used to achieve coherence and cohesion.

\section{Methodology}

The participants of the current study were 100 students from various schools at Kolej Universiti Poly-Tech MARA, Kuala Lumpur. They consisted of 68 females and 32 males. For the purpose of administering the treatment, which was teaching them to write academic texts using an approach that was designed based on observational learning developed from Bandura's social learning theory, the participants were placed into two classes of equal numbers.

This experimental study was executed in the following manner: firstly, three pre-tests were administered on the participants within a period of one week in which they were required to write three different types academic essays, namely; an argumentative, a discursive and a comparison and contrast essay. Each of these essays were 300 to 400 words in length and were to be completed within a period of two hours. Secondly, the participants were given the treatment in which they were taught how to write argumentative essay using the earlier mentioned approach. A week after the treatment, a post-test was administered to the participants in which they were asked to write an argumentative essay whose title was the same as the one given for the pretest. The second treatment session and the second post-test were carried out in a similar manner a week after the first post-test. The same went for the third treatment session and the third post-test.

The data for the study was procured from the pre-test and post-test assessments for the three types of academic essays. Then, paired T-test statistical analyses were used to determine whether there were any improvements in the participants' writing performances in terms of content, organization, vocabulary, language use and mechanics after being taught writing styles using the approach mentioned above.

\section{Results}

The following are the results of the paired T-tests for the three essays, in terms of the five aspects tested.

\subsection{Paired T-test for the three academic essays in terms of content.}

The paired T-test differential analyses between the pre-tests and the post-tests of the participants in the three types of essays in terms of content: 
Table 1. Paired T-test in terms of content.

\begin{tabular}{|c|c|c|c|c|c|c|c|}
\hline Type of Essay & Test & Mean & SD & $\begin{array}{l}\text { Mean } \\
\text { Diff }\end{array}$ & $\mathbf{t}$ & df & $\begin{array}{l}\text { Sig (2-diff } \\
\text { tailed) }\end{array}$ \\
\hline \multirow{2}{*}{$\begin{array}{l}\text { Argumentative } \\
\text { Essay }\end{array}$} & Pre & 16.31 & 2.581 & \multirow{2}{*}{5.20} & \multirow{2}{*}{15.788} & \multirow{2}{*}{99} & \multirow{2}{*}{.000} \\
\hline & Post & 21.51 & 2.312 & & & & \\
\hline \multirow{2}{*}{$\begin{array}{l}\text { Discursive } \\
\text { Essay }\end{array}$} & Pre & 21.79 & 2.119 & \multirow{2}{*}{1.39} & \multirow{2}{*}{4.663} & \multirow{2}{*}{99} & \multirow{2}{*}{.000} \\
\hline & Post & 23.18 & 2.134 & & & & \\
\hline \multirow{2}{*}{$\begin{array}{l}\text { Comparison and } \\
\text { Contrast Essay }\end{array}$} & Pre & 23.15 & 2.615 & \multirow{2}{*}{3.23} & \multirow{2}{*}{8.901} & \multirow{2}{*}{99} & \multirow{2}{*}{.000} \\
\hline & Post & 26.38 & 2.891 & & & & \\
\hline
\end{tabular}

Table 1 above shows the comparisons for the T-test differential analyses between the performances of the participants in the pre-test and their performances in the post-test, in terms of content, for the three types of essays. The findings from the analyses indicate that the participants' post-test results had significantly higher scores than those of their pre-test, under the condition that $d$ has a large effect size. Hence, the differences are large according to Cohen's (1988) guideline. All of the results show that there are significant differences in the performances of the participants in the three types of academic essays in terms of content after being taught using the approach.

\subsection{Paired T-test for the three academic essays in terms of organization.}

The paired T-test differential analyses between the pre-tests and the post-tests of the participants in the three types of essays terms of organization:

Table 2. Paired T-test in terms of organization.

\begin{tabular}{|c|c|c|c|c|c|c|c|}
\hline Type of Essay & Test & Mean & SD & $\begin{array}{l}\text { Mean } \\
\text { Diff }\end{array}$ & $\mathbf{t}$ & df & $\begin{array}{l}\text { Sig (2-diff } \\
\text { tailed) }\end{array}$ \\
\hline \multirow{2}{*}{$\begin{array}{l}\text { Argumentative } \\
\text { Essay }\end{array}$} & Pre & 12.28 & 1.965 & \multirow{2}{*}{3.23} & \multirow{2}{*}{18.196} & \multirow{2}{*}{99} & \multirow{2}{*}{.000} \\
\hline & Post & 16.44 & 1.452 & & & & \\
\hline \multirow{2}{*}{$\begin{array}{l}\text { Discursive } \\
\text { Essay }\end{array}$} & Pre & 15.47 & 1.114 & \multirow{2}{*}{1.56} & \multirow{2}{*}{10.09} & \multirow{2}{*}{99} & \multirow{2}{*}{.000} \\
\hline & Post & 17.03 & 1.159 & & & & \\
\hline \multirow{2}{*}{$\begin{array}{l}\text { Comparison and } \\
\text { Contrast Essay }\end{array}$} & Pre & 15.13 & 1.600 & \multirow{2}{*}{2.71} & \multirow{2}{*}{11.98} & \multirow{2}{*}{99} & \multirow{2}{*}{.000} \\
\hline & Post & 17.84 & 1.619 & & & & \\
\hline
\end{tabular}

Table 2 above shows the comparisons for the T-test differential analyses between the performances of the participants in the pre-test and their performances in the post-test, in terms of organization, for the three types of academic essays. The findings from the analyses indicate that the participants' post-test results were significantly higher than those of their pre-test, under the condition that $d$ has a large effect size. Hence, the differences are large according to Cohen's (1988) guideline. All of the results show that there are significant differences in the performances of the participants in the three types of academic essays, in terms of organization, after being taught using the approach.

\subsection{Paired T-test for the three academic essays in terms of vocabulary.}

The paired T-test differential analyses between the pre-tests and the post-tests of the participants in the three types of essays, in terms of vocabularyL 
Table 3. Paired T-test in terms of vocabulary.

\begin{tabular}{|c|c|c|c|c|c|c|c|}
\hline Type of Essay & Test & Mean & SD & $\begin{array}{l}\text { Mean } \\
\text { Diff }\end{array}$ & $\mathbf{t}$ & df & $\begin{array}{l}\text { Sig (2-diff } \\
\text { tailed) }\end{array}$ \\
\hline \multirow{2}{*}{$\begin{array}{l}\text { Argumentative } \\
\text { Essay }\end{array}$} & Pre & 12.80 & 1.758 & \multirow{2}{*}{3.11} & \multirow{2}{*}{14.011} & \multirow{2}{*}{99} & \multirow{2}{*}{.000} \\
\hline & Post & 15.91 & 1.408 & & & & \\
\hline \multirow{2}{*}{$\begin{array}{l}\text { Discursive } \\
\text { Essay }\end{array}$} & Pre & 14.16 & 1.261 & \multirow{2}{*}{2.16} & \multirow{2}{*}{12.271} & \multirow{2}{*}{99} & \multirow{2}{*}{.000} \\
\hline & Post & 16.32 & 1.222 & & & & \\
\hline \multirow{2}{*}{$\begin{array}{l}\text { Comparison and } \\
\text { Contrast Essay }\end{array}$} & Pre & 14.92 & 1.643 & \multirow{2}{*}{2.77} & \multirow{2}{*}{13.518} & \multirow{2}{*}{99} & \multirow{2}{*}{.000} \\
\hline & Post & 17.69 & 1.390 & & & & \\
\hline
\end{tabular}

Table 3 shows the comparisons for the T-test differential analyses between the performances of the participants in the pre-test and their performances in the post-test in the three types of academic essays, in terms of vocabulary. The findings from the analyses indicate that the participants' post-test results were significantly higher than those of their pre-test, under the condition that $d$ has a large effect size. Hence, the differences are large according to Cohen's (1988) guideline. All of the results shows that there are significant differences in the performances of the participants in the three types of academic essays, in terms of vocabulary, after being taught using the approach.

\subsection{Paired T-test for the three academic essays in terms of language use.}

The paired T-test differential analyses between the pre-tests and the post-tests of the participants in the three types of academic essays, in terms of language use:

Table 4. Paired T-test in terms of language use.

\begin{tabular}{|c|c|c|c|c|c|c|c|}
\hline Type of Essay & Test & Test & SD & $\begin{array}{l}\text { Mean } \\
\text { Diff }\end{array}$ & $t$ & df & $\begin{array}{l}\text { Sig (2-diff } \\
\text { tailed) }\end{array}$ \\
\hline \multirow{2}{*}{$\begin{array}{l}\text { Argumentative } \\
\text { Essay }\end{array}$} & Pre & 12.00 & 1.385 & \multirow{2}{*}{4.25} & \multirow{2}{*}{12.542} & \multirow{2}{*}{99} & \multirow{2}{*}{.000} \\
\hline & Post & 16.25 & 3.069 & & & & \\
\hline \multirow{2}{*}{$\begin{array}{l}\text { Discursive } \\
\text { Essay }\end{array}$} & Pre & 13.57 & 1.539 & \multirow{2}{*}{3.12} & \multirow{2}{*}{17.074} & \multirow{2}{*}{99} & \multirow{2}{*}{.000} \\
\hline & Post & 16.69 & 1.308 & & & & \\
\hline \multirow{2}{*}{$\begin{array}{l}\text { Comparison and } \\
\text { Contrast Essay }\end{array}$} & Pre & 19.87 & 2.330 & \multirow{2}{*}{3.12} & \multirow{2}{*}{11.041} & \multirow{2}{*}{99} & \multirow{2}{*}{.000} \\
\hline & Post & 22.99 & 2.195 & & & & \\
\hline
\end{tabular}

Table 4 shows the comparisons for the T-test differential analyses between the performances of the participants in the pre-test and their performances in the post-test in the three types of academic essays, in terms of language use. The findings from the analyses indicate that the participants' post-test results were significantly higher than those of their pre-test, under the condition that $d$ has a large effect size. Hence, the differences are large according to Cohen's (1988) guideline. All of the results show that there are significant differences in the performances of the participants in the three types of academic essays, in terms of language use, after being taught using the approach.

\subsection{Paired T-test for the three academic essays in terms of mechanics.}

The paired T-test differential analyses between the pre-tests and the post-tests of the participants in the three types of academic essays, in terms of mechanics: 
Table 5. Paired T-test in terms of mechanics.

\begin{tabular}{|c|c|c|c|c|c|c|c|}
\hline Type of Essay & Test & Mean & SD & $\begin{array}{l}\text { Mean } \\
\text { Diff }\end{array}$ & $\mathbf{t}$ & df & $\begin{array}{l}\text { Sig (2-diff } \\
\text { tailed) }\end{array}$ \\
\hline \multirow{2}{*}{$\begin{array}{l}\text { Argumentative } \\
\text { Essay }\end{array}$} & Pre & 2.78 & 0.629 & \multirow[t]{2}{*}{0.640} & \multirow[t]{2}{*}{6.674} & \multirow[t]{2}{*}{99} & \multirow[t]{2}{*}{.000} \\
\hline & Post & 3.42 & 0.727 & & & & \\
\hline \multirow{2}{*}{$\begin{array}{l}\text { Discursive } \\
\text { Essay }\end{array}$} & Pre & 2.75 & 0.557 & \multirow{2}{*}{0.650} & \multirow{2}{*}{9.078} & \multirow{2}{*}{99} & \multirow{2}{*}{. 000.} \\
\hline & Post & 3.40 & 0.512 & & & & \\
\hline \multirow{2}{*}{$\begin{array}{l}\text { Comparison and } \\
\text { Contrast Essay }\end{array}$} & Pre & 3.22 & 0.705 & \multirow{2}{*}{0.540} & \multirow{2}{*}{5.058} & \multirow{2}{*}{99} & \multirow{2}{*}{.000} \\
\hline & Post & 3.76 & 0.740 & & & & \\
\hline
\end{tabular}

Table 5 shows the comparisons for the T-test differential analyses between the performances of the participants in the pre-test and their performances the post-test in the three types of academic essays, in terms of mechanics. The findings from the analyses indicate that the participants' post-test results were significantly higher than those of their pre-test, under the condition that $d$ has a large effect size. Hence, the differences are large according to Cohen's (1988) guideline. All of the results show that there are significant differences in the performances of the participants in the three types of essays, in terms of mechanics, after being taught using the approach.

\section{Discussion}

During the three treatment sessions in the study, the participants had been instructed and guided to observe or analyze samples of the three types of essays. They were also encourage to imitate or copy the organization, language use and style of the author of the model texts. Nonetheless, in the case of language use and vocabulary, the participants were taught to emulate the ones in the model text, meaning that they had to match or surpass the authors' use of language and vocabulary by imitating them. In an effort to prevent the participants from plagiarizing, they were taught to paraphrase and summarize as well as synthesize the ideas and supporting details of the model texts. It was also specified that they should do the same when taking ideas and supporting details from other sources. This implies that they had to read widely. While reading they were also explicitly told to take notice of the correct usage of mechanics in academic texts. Throughout the treatment session, the participants were reminded to not only copy, but emulate the model texts. This was the primary reason why the participants had shown improvements in all of the aspects of writing, namely; content, organization, vocabulary, language use and mechanics tested in the post-test.

Ahn (2012) refers to the above described activities in the treatment session as "active scaffolding processes" and believes that they are most beneficial when carried out in the early phase of a writing cycle where an instructor can overtly point out to students the different ways texts are written (Ahn, 2012, p.2). In iterating Vygotsky (1978), Ahn (2012) posits that these "active scaffolding processes" or an instructor who through cooperative or collaborative dialogue between students and instructor or students and their peers provide them with appropriate assistance that can help develop their confidence and positive attitude towards writing. Ahn's (2012) allegation above is also supported by Badger and White (2000), Chow (2007); Md Omar, Lee, and Jamil (2013), Hyland (2003a, 2004), Johns (1997), Maleerat Ka-kan and Sarjit Kaur (2015), Martin (1993), Ting, Campbell, Law, and Poh (2013), Sajid and Saddiqui (2015), Siallagan (2014) and Swchwieter (as cited in Zangoei \& Davoudi, 2016).

With reference to this present study, the participants scored higher marks for content and organization in the post-test because firstly, during the treatment sessions they had been guided in their analyses of the sample texts to notice not only the ideas of the model texts but the different ways these ideas were organized and written in each type of text. The participants realized that for their essays to be considered well-written, their ideas must be apposite, well-developed and supported by appropriate detail. The participants were taught to develop a good thesis statements and topic sentences by observing and emulating those of the authors' in the 
sample texts. Next, they were asked to observe and emulate the way these authors supported their thesis statements and topic sentences with substantive detail. Then, they were shown how the latter develop their ideas through elaboration by using facts or other pertinent details so as to make those ideas both logical and convincing. This finding of the efficacy of the above described observation and emulation is consistent with the findings of studies that have been undertaken by Badger and White (2000), Chow (2007), Md Omar et al (2013), Hyland (2003a, 2004), Johns (1997), Maleerat Ka-kan and Sarjit Kaur (2015), Martin (1993), Ting et al (2013), Sajid and Saddiqui (2015) and Siallagan (2014).

According to Flowerdew (as cited in Johns, 2002), it is generally difficult for L2 students to write a coherent and cohesive text to meet specific academic requirements. This is, however, not the case with the participants in this study because they were found to have scored higher marks in organization in the post-test. This is because the observation of the model texts had provided the participants with knowledge of the generic features of any type of genre thus insight into the working of that genre. Once they understood the structural patterns of the target genre, they were able to identify the strategies used by writers to achieve their communicative purposes and the occurrence of obligatory and optional moves and the sequence of these moves (Osman, 2004; Md Omar et al, 2013; Badger \& White, 2000; \& Martin, 1993). Furthermore, since the genre-based approach considers writing as largely linguistic (Atkinson, 2003; Cheng, 2006, 2007, 2008; Hyland, 2003a, 2003b, 2007; Johns, 2003; Paltridge, 1996, 2000, 2002, 2004, 2007; \& Swami, 2008), another reason as to why the participants of this study had improved in terms of organization in the post test was because they had been taught to also observe and learn how coherence and cohesion could be achieved through linguistic means.

In order to gain the ability to construct unambiguous, grammatically correct as well as parallel sentences and choose appropriate vocabulary and expressions, the participants of the present study had been taught to emulate the mothods employed by the authors in the model texts. This had enable them to not only develop their vocabulary and language use but simultaneously augment those they already have in their mind. Hyland (2004) also argues that 'an understanding of the ways of the language is used to create meanings in writing empowers teachers by offering them ways to analyze texts to reflect on the working of language, and to provide more robust and targeted support for learners' (Hyland, 2004, p. 162). Hyland (2004) in fact, considers the genre-based approach as teachers' needful response to students' endeavors in learning to write in a second or foreign language. After all, 'a well-formulated theory of how language works in human interaction has become an urgent necessity in the field of teaching second language writing'. This is because the approach enables students to identify the recursive features of any genre employed in academic and professional settings 'through consciousness-raising and linguistic awareness tasks' (Ahn, 2012, p.3).

Besides that, Ahn (2012), Cheng (2006), and Hyland (2003a, 2007) feel that students should explicitly be made aware of the recursive textual features of any genre as these can assist them in learning to write. Furthermore, by analyzing different types of texts, students will be able to understand the nature of English features in them. The participants' awareness of the elements of grammar or patterns of vocabulary in the sample text of each type of essays was boosted in the same manner. These improvements in vocabulary was, in fact, reflected in Md Omar's et al (2013) study, after the participants were taught to use a genre-based approach. This is why the participants in this study had also performed better in terms of vocabulary and language use in the post-test as compared to their performance in the pre-test. This finding concurs with that of Hyland's (2003a) who believes that students need to be taught to observe and emulate the language patterns in the sample texts so as to create not only an ideal but purposeful composition. Then, with varying degrees of help, the participants of this study were asked to produce partial texts. Finally, they were instructed to produce a whole essay on their own (Badger and White 2000). Last but not least, the participants' better performance in terms of mechanics in the post-test compared to their performance in the same aspect in the pre-test was also due to the same reasons mentioned above and can be explained as such.

The above discussion is based on the findings made on the sample size of only 100 students of Kolej Universiti Poly-Tech MARA. Moreover, due to some restrictions, it was not possible to select the mentioned sample through random sampling. Therefore, convenience sampling was used instead. The results of this 
research therefore cannot be generalized to all students of institutions of higher learning in Malaysia or elsewhere. As such, for the purpose of generalization of the results, a larger scale research involving a bigger sample size from various institutions of higher learning is suggested for future studies. In addition, it is suggested that future studies could explore the use of a more robust sampling methodology. Other than that, only five components of the written essays were assessed, namely; content, organization, vocabulary, language use and mechanics. This study did not assess the specific ability of students to cite information from other sources as well as to paraphrase, summarize, synthesize, and reference it. These are other areas to dwell upon in future research for these are important parts of academic writing too. The ability of writing an academic text should be developed not only at a tertiary level but also at a high school level. Since writing folios are a part of the evaluation of students' performances in schools in subjects like History, Geography and Living Skills, it is necessary to teach students how to write academic texts effectively.

\section{Conclusion}

This study reveals the pedagogical benefits of using a genre-based approach which has been specifically designed to embody Bandura's observational learning to teach academic writing. The approach recommends that academic writing be learned by teaching students overtly to recognize the recursive features of any genres through the observation and emulation of sample texts. Observational learning of sample texts provides students with guidance on how to improve their writing as it makes them aware of the different ways texts are organized for different communicative purposes, as well as promoting their confidence and positive attitude towards writing. It also demonstrates the importance of the role of an instructor in helping to improve their students' writing. The act of emulation of sample texts, on the other hand, helps both instructors and students to address the many obstacles they experience in the teaching and learning of writing. In addition, a genrebased approach, such as the one used in this study, is an effective method of teaching writing because many novice writers often do not know what they want to write about beforehand. Students are able to explore many ideas when they are exposed to sample texts. Moreover, an understanding of the ways that language can be used by instructors to create meanings in writing in turn helps them to analyze texts and to reflect on the workings of language, so that they can provide more robust and targeted support for their students.

\section{References}

Ahn, H. (2012). Teaching writing skills based on a genre approach to L2 primary school students: An action research. English Language Teaching, 5(2), 2-16.

Atkinson, D. (2003). L2 writing in the post-process era: Introduction. Journal of Second Language Writing, 12(1), 3-15, doi.org/10.1016/S1060-3743 (02)00123-6

Badger, R. \& White, G. (2000). A process genre approach to teaching writing. ELT Journal, 54(2), 153-160.

Bandura, A. (1965) Influence of models' reinforcement contingencies on the acquisition of imitative response. Journal of Personality and Social Psychology, 1, 589-595.

Bandura, A. (1971) Social Learning Theory. New York: General Learning Press.

Bandura, A. (1977) Social Learning Theory. New York: General Learning Press.

Bhatia, V. K. (2002). A generic view of academic discourse. In J. Flowerdew (Ed.), Academic discourse (pp. 21-39) Harlow: Longman.

Bidabadian, H. \& Tabatabaei, O. (2015). The relationship between Iranian EFL institutes teachers' beliefs and their instructional practices regarding writing strategies. Theory and Practice in Language Studies, 5(9), 1828-1835, doi.org/10.17507/tpls.0509.09

Cheng, A. (2006). Understanding learners and learning in ESP genre-based writing instruction. English for Specific Purposes, 25(1), 76-89, doi.org/10.1093/elt/54.2.15

Cheng, A. (2007). Simulation-based L2 writing instruction: Enhancement through genre analysis. Simulation \& Gaming, 38(1), 67-82, doi.org/10.1177/1046878106297879 
Cheng, A. (2008). Analyzing genre exemplars in preparation for writing: The case of an L2 graduate student in the ESP genre-based instructional framework of academic literacy. Applied linguistics. 29(1), 50-71, doi.org/0.1093/applin/amm021

Cherry, K. (2016). What is social learning theory? Retrieved from https://www.verywell.com/social-learning-theory2795074

Chow, T. V. F. (2007). The effects of the process-genre approach to writing instruction on the expository essays of ESL students in a Malaysian secondary school (Unpublished doctoral thesis), Universiti Sains Malaysia, Malaysia.

Cohen, J. (1988). Statistical power analysis for the behavioral sciences (2nd ed.). Hillsdale, NJ: Lawrence Erlbaum Associates.

Hyland, K. (2003a). Genre-based pedagogies: A social response to process. Journal of Second Language Writing, 12(1), 17-29, doi.org/10.1016/S1060-3743 (02)00124-8

Hyland, K. (2003b). Second language writing. New York: Cambridge University Press.

Hyland, K. (2004). Genre and second language writing. Ann Arbor: University of Michigan Press.

Hyland, K. (2007). Genre pedagogy: Language, literacy and L2 writing instruction. Journal of Second Language Writing, $16,148-164$.

Johns, A. (2003). Genre and ESL/EFL composition instruction. In B. Kroll (Ed.), Exploring the dynamics of second language writing (pp. 195-217). Cambridge: Cambridge University Press.

Johns, A. M. (1997). Text, role, and context: Developing academic literacies. Cambridge: Cambridge University Press.

Johns, A. M. (Ed.). (2002). Genre in the Classroom: Multiple perspectives. Mahwah, NJ: Lawrence Erlbaum.

Johns. A. M. (2008). Genre awareness for the novice academic writing. Language Teaching, 41 (2), 237-52.

Maleerat Ka-kan Dee \& Sarjit Kaur (2015). Teaching strategies used by Thai EFL lecturers to teach argumentative writing. Procedia- Social and Behavioral Sciences, 208(2015), 143 -156

Martin. J. R. (1993). A contextual theory of language. In B. Cope and M. Kalantzis (Eds.) The power of literacy: A Genre approach to Teaching Writing (pp.137-153). London: Falmer Press.

Md. Omar, H., Lee, B. S. N., \& Jamil, S. B. H. (2013). Assisting pre-university ESL learners to gain control of the report writing based on graphical data: A genre-based approach. Journal of Education and Practice, 4 (1), 19-30.

Osman, H. (2004) Genre-based instruction for ESP. The English Teacher, 33, 13-29.

Paltridge, B. (1996). Genre, text type, and the language learning classroom. ELT Journal, 50(3), 237-243.

Paltridge, B. (2000). Genre analysis. In B. Paltridge (Ed.), Making sense of discourse analysis (pp. 105-126). Gold Coast, QLD: Antipodean Educational Enterprises.

Paltridge, B. (2002). Genre, text type, and English for Academic Purposes (EAP). In A. M. Johns (Ed.), Genre in the classroom: Multiple Perspectives (pp.73-90). Mahwah, NJ: L. Erlbaum.

Paltridge, B. (2004). Approaches to Teaching Second language Writing. Proceedings of $17^{\text {th }}$ Educational Conference, Adelaide, Australia. Retrieved from celta.wikispaces.com/file/view/Paltridge,pdf/30724017

Paltridge, B. (2007). Approaches to Genre in ELT. In J. Cummins, \& C. Davison (Eds.), International Handbook of English Language Teaching (pp. 931-943), 15, Springer US.

Sahin, M. \& Genc, B. (2015). Writing self-efficacy of international students learning Turkish as a second language. The Reading Matrix, 15(2), 210-217.

Sajid, M. \& Siddiqui, J. A. (2015). Lack of academic writing skills in English at higher education level in Pakistan: Causes, effects and remedies. International Journal of Language and Linguistics, 2(4), 174-186.

Samsudin, Z. (2013). Using the process approach in writing academic texts among first-year undergraduates of an institution of higher learning. Unpublished doctoral thesis: University of Selangor, Malaysia.

Siallagan, C, A. (2014), Genre-based approach: Theories, lesson plan and teaching simulation. Retrieved from www.academia.edu/4743498/GenrebasedApproach.

Swami, J.A. (2008). Sensitizing ESL students to genre: TESL-EJ. 13(3), 1-13. http://www.tesl-ej.org/ej47/a9.html

Ting, S.H., Campbell, Y. M., Law, L., \& Poh, H. H. (2013). Explanations without a purpose? Genre-based instruction and academic writing. Journal of Academic Language and Learning, 7(1), 26-40.

Vygotsky, L. S. (1978). Mind in society: The Development of higher psychological processes. Cambridge, MA: Harvard University Press.

Zangoei, A. and Davoudi, M. (2016). Socially constructed mechanism in EFL writing: A case study of scaffold planning in a remote area. Pertanika Journal of Social Sciences. \& Humanities, 24(4), 1279 - 1291. 